\title{
Self-Organisation in Lifelong Learning: Theory, Practice and Implementation Experience Involving Social Networks and a Remote Format
}

\author{
Mario De Martino', Yulia Sh. Gushchina ${ }^{1}$, Zlata V. Boyko', \\ Angela Magnanini' ${ }^{2}$, Iosif Sandor ${ }^{3}$, \\ Berta Alicia Guerrero Perez ${ }^{4}$, Emanuele Isidori ${ }^{2}$ \\ ${ }^{1}$ Peoples' Friendship University of Russia (RUDN University) \\ 6 Miklukho-Maklaya St, Moscow, 117198, Russian Federation \\ ${ }^{2}$ Foro Italico University of Rome \\ 6 Piazza L. De Bossis, Rome, 00135, Italian Republic \\ ${ }^{3}$ Babeș-Bolyai University \\ 7 Strada Pandurilor, Cluj-Napoca, 400000, Romania \\ ${ }^{4}$ De la Cruz \& Associates, Attorneys at Law \\ 74E Carrasquilla St, Panama City, 0823, Zona 7, Republic of Panama
}

\begin{abstract}
Currently, in the context of the global transition of the world education system to the remote format, it has become vitally important for a person to be able and ready to independently organise his/her educational and professional activities. The article considers methodological approaches to self-education in the context of its use in the process of lifelong learning/ continuous education. The authors discuss the existing concepts of self-education and ways of its organisation, taking into account age-specific features, forms and types of learning. The concepts of 'self-organisation' and 'self-education' are analysed. The essence of the scientific categories 'self-learning' and 'self-organisation in education' is revealed in relation to the system of higher education. The role of tutors as mediators in student self-organisation is shown and their main functions in this process are described. Based on a theoretical analysis of existing forms of self-organisation in education and the experience of using self-organisation, various directions and possibilities of their application in practice are delineated. Careful consideration is given to criticism of the use of self-organisation in learning and its advantages. The authors also discuss the prospects of using self-organisation in higher education, emphasising the importance and relevance of developing self-organisation as a student's personality trait. A description is made of learning models based on self-organisation of students. Finally, the experience of implementing the self-organisation approach to the educational process is analysed. As a result of the study, the authors conclude that self-learning can be successful if it seems socially significant for students. The use of advanced digital technologies and Internet resources can also contribute to effective self-learning. The results of the study indicate that students should develop the ability to independently organise their educational activities as
\end{abstract}

(C) De Martino M., Gushchina Yu.Sh., Boyko Z.V., Magnanini A., Sandor I., Guerrero Perez B.A., Isidori E., 2020 
well as self-control/self-assessment skills, which is especially important in connection with the increase in independent work in curricula and the massive transition to the remote format in higher education during the COVID-19 pandemic.

Key words: lifelong learning, self-education, self-organisation of students, continuing education, remote education, social network

\section{Introduction}

The globalisation and modernisation of modern society requires new approaches to education. Individuals who are able to ensure their competitiveness throughout their lives are very much in demand today. The constant influx of new knowledge accompanied by increasing volumes of information and emerging new technologies lead to the need to improve skills and develop the creative capacities of individuals. Therefore, learning activities should be focused not so much on increasing quantitative indicators of knowledge but on developing certain skills to solve specific problems and tasks.

The concept of lifelong education involves the acquisition of new knowledge throughout life, using both formal and informal learning models (Boyko et al., 2014; Belovol et al., 2019). The formal learning model is implemented in educational institutions at various levels and is confirmed by official documents (certificates, diplomas). Informal learning takes place in the process of everyday life, often without a special educational task. In recent years, due to the significant development of the science of education and the concept of lifelong learning, the importance of the educational process has been identified, in which it is necessary to help students to understand the process of their own learning and make them able to assess their own experience.

Consequently, the internal and external aspects of the individual learning process, such as the motivation for acquiring certain skills, the decision-making system necessary to optimise the learning process, the ability to manage it and direct it towards achieving goals related to the needs and interests of students, become the most important factors that determine the success or failure of learning itself (Knyazkova, 2014).

The idea of self-education and self-learning throughout one's life originates in the philosophies of Socrates, Plato and Aristotle, who linked the process of self-education with the possibility of personal self-improvement and self-development (Aristotle, Plato). Later, R. Descartes proposed the hypothesis of self-organisation, which was further developed by I. Kant (Descartes, Kant). These ideas were further elaborated in pedagogy and psychology. In the context of the concept of lifelong education, which became popular in the 70s of the twentieth century, the ideas of self-education, self-learning and self-organisation gained particular relevance.

In 1996, the Organisation for Economic Co-operation and Development (OECD) emphasised the importance of helping people, starting at the initial level of education, to develop skills and acquire knowledge that would enable them to selfdevelop constantly and throughout their lives, to retain the ability to learn and actively monitor the dynamics of their own learning (OECD-OCSE, 1996).

Later, in the 2013 message, revised in 2017 and addressed to the European Parliament, the European Economic and Social Committee and the Committee of 
the Regions, on technology and educational resources, the European Commission emphasised the importance of promoting the conditions and rules of an open educational process based on 'self-directed' learning, aimed at the formation of thinking and responsibility among students who can independently plan their educational process, find resources and, therefore, consciously participate in the learning process and achieve results. This approach, according to the European Commission, should also be encouraged by the use of open educational resources (Cfr. Commissione Europea, 2013). Self-directed learning is currently an indicator that reflects how a person is able to determine what, when and how to teach, as well as an integral part of the need that must be met through the constant search for new educational opportunities. The conceptual transition from education to self-education is a promising direction in the development of higher education. Self-organisation is a prerequisite and part of the process of self-education.

\section{Self-organisation in learning: a comprehensive concept}

The aim of our study is to consider the existing pedagogical and psychological approaches to the organisation of self-education, which is one of the leading forms of lifelong learning, as well as to make a comparative analysis of various forms of self-organisation in higher education.

Due to the increased relevance of self-education in recent years, a number of questions have arisen related to the process of organising self-education, such as selforganisation, self-motivation, self-learning and some others. 'Self-education' and 'selforganisation' as scientific categories are considered in philosophy, pedagogy, psychology, sociology and cultural studies due to the interdisciplinary content of these concepts. M. Knowles emphasised that self-education is not only a basic, specifically human ability but also the cornerstone of the lifelong learning process (Knowles, 1975).

The ability to 'manage oneself', 'self-control' and 'self-organisation' in many ways allows us to assess the level of personal development. Self-organisation is a fundamental indicator for assessing the development level achieved by an individual, both in terms of personal maturity and intellectual and professional development; it also determines the degree of active participation of students in planning, conducting, assessing and understanding the learning option selected and implemented by them based on their interests and needs (Brockett, Hiemstra, 1991).

M. Narváez and A. Prada believe that self-organisation in learning can be identified with the concept of 'self-directed learning', which, in turn, is synonymous to 'self-regulated', 'autonomous' and 'programmed' learning, since in all these forms of learning the key element will be personal initiative, which is described as the basis or rather the 'starting point' from which individuals begins to set goals and manage their resources in order to achieve the set goals (Narváez, Prada, 2005. Pp. 115-146). Self-organisation is manifested in the ability to take on growing responsibility in the process of self-learning, set specific goals, allocate the necessary resources for learning, plan educational activities, choose strategies, monitor the development of actions, constantly assess learning outcomes and reflect on one's own actions.

An analysis of Russian psychological and pedagogical studies of self-organisation showed that there are many different approaches to understanding this phe- 
nomenon. Some authors consider self-organisation as self-direction of their own actions sorted in order of importance and aimed at achieving a goal (Mandrikova, 2010); others believe that self-organisation is an integrated system-forming complex of personality traits that affects the effectiveness of activities (Smolyar, Knyazkova, 2016); A.M. Pavlova understands self-organisation as the ability to create a system of independent self-directive actions that ensure the productivity of activities (Pavlova, 2017).

Self-organisation in self-education is actually a starting point for lifelong learning, understood as a state of constant search for opportunities to acquire new knowledge. Moreover, it is 'self-organisation' (which includes the process of selfcontrol and self-motivation) that allows individuals to start the processes associated with lifelong learning, that is, to perceive themselves as 'students' and 'researchers' throughout their existence (Belovol et al., 2016). Education in a university is an important factor affecting the formation of personalities; self-organisation as a personality trait is developed in the process of self-education.

Therefore, it can be said that self-organisation depends on the level of personal predisposition to lifelong learning and on the 'quality' of learning in terms of knowledge acquisition, ability to change and develop skills (Merrian, Caffarella, 1991). It is obvious that individuals who have developed the ability to control themselves can manifest themselves as personalities focused on lifelong learning (Artelt et al., 2003. P. 10). The desire and capacity for continuing learning are manifested in an individual due to the appearance of 'specific signs' associated with internal motivation, personal interest and independence in the organisation and management of self-directed learning. As a matter of fact, self-organisation helps to determine the level of understanding of the importance and value that an individual attaches to the educational process and learning as a whole, as a set of actions aimed at achieving personal independence in various spheres of life.

Self-organisation is a prerequisite for self-learning, which must be started and completed; and, in this sense, we can assume that self-organisation is not identified with self-learning, since it exists for the latter in the framework of the individual's state, which we can define as 'the internal human nature' (in interiore homine). Despite the fact that self-organisation is related to the internal human nature and predisposition to learning values, the trend towards independence in learning can be predicted and assessed using specific methods and tools obtained thanks to them (Olivares, López, 2014).

Experimental studies show that the trend towards personal self-organisation arises almost naturally, and then turns into the ability to independently plan and manage enthusiasm, trust in learning strategies and educational values along with responsibility. The study conducted by R.T. Owen shows that the learning process of an individual focused on self-education always proceeds freely and without a sense of restriction, regardless of whether it occurs in an informal environment or in formal areas, in which, however, there are obstacles to the free study of the curriculum content (Owen, 1999. Pp. 739-743).

However, some authors believe that it is precisely because of the limitations associated with certain requirements and standards that self-directed learning (as a consequence of self-organisation) cannot be successfully developed within 
the formal, traditional educational context (Brookfield, 2001). At the same time, adult education in most cases can be very successful using a model of informal education, which involves self-learning (Belovol et al., 2018; Candy, 1991). In fact, one of the fundamental concepts related to self-organisation and learning is the ability to learn independently and, therefore, also become 'self-educated'.

Traditionally, students were perceived as subjects in an 'inactive' learning environment, that is, as passive receivers of content taught in a non-emotional and nonpersonalised format; the use of their own approaches and personal resources by themselves, as it should be in the context of self-learning, was not encouraged (Merrian, Caffarella, 1991). At the same time, the modern reform of the education system, which is based on the model of lifelong learning, requires the introduction of new learning methods.

The most effective educational model, consistent with the principles of democratic values and highly-demanded in modern society, is manifested in the fact that it is perceived as an environment, not isolated but acting in symbiosis with all other educational contexts and with society as a whole, in order to promote the development of students' independence. In this environment, students, as active subjects, can find, for example, just that component of freedom that will be available thanks to new Internet technologies and remote learning formats that allow students to find resources and tools for developing and conducting self-directed learning outside the formal educational content provided by the institution (Kop, Fournier, 2010. Pp. 2-19).

The educational model, based on the self-organisation development principles, assumes that teachers act rather as learning assistants, which allows students to use the knowledge and skills that they personally acquired, consciously choosing various cognitive strategies in accordance with their tasks, as well as to develop a constant motivation to learn using the resources that society and new technologies provide for them (Cázares, 2009. Pp. 1-4).

The current trend towards self-organisation in learning makes it possible to develop and implement an integrated learning model that includes different learning strategies (cognitive, metacognitive and motivational ones). This model involves the development of the ability to control emotions (understood as the ability to create and control the desire and enthusiasm for learning), as well as continuous self-improvement and personal growth, which involves the development of the ability to reflect, the ability to rethink the acquired experience and set new learning goals (Smolyar, Knyazkova, 2016).

The modern concept of self-education as a result of self-organisation in education is a complex of key provisions based on experimental data obtained using specific educational models and theories of personality formation. There is no doubt that in the context of adult education, where the goal and the means to achieve it are more easily defined, self-education is the very essence of lifelong learning. Selforganisation, as the starting point and essence of adult education, reflects the nature of self-education, which, according to M. Gibbons and G. Phillips, can really be implemented only when some people are not forced to study, and others are not obliged to teach the content of a particular educational programme (Gibbons, Phillips, 1982. Pp. 67-86). In fact, self-learning is implementable only when students independently decide what to learn and what not to learn. 
M. Knowles notes that self-organisation in learning involves the direct participation of students in the educational process, their taking the initiative, with or without someone else's help, in diagnosing their learning needs, formulating learning goals, identifying learning resources, choosing and implementing appropriate learning approaches and assessing subsequent results (Knowles, 1970).

At present, educational theorists consider self-organisation in learning as a lifestyle that underlies independent learning (i.e. self-directed learning). Self-learning allows each student to take more responsibility for learning-related decisions. Selforganisation in learning can be considered as a characteristic that, to one degree or another, exists at all stages of human education. Self-learning can include various activities and involve various resources, such as reading self-selected literature, participating in learning circles and discussions, internships, or simple self-description of material (Brockett, Hiemstra, 1991). A teacher or tutor can contribute to the autonomous and free development of self-education of students by maintaining a constant dialogue with them, providing them with resources, assessing their results and promoting the development of their critical and abstract thinking. Educational institutions can support self-organisation in learning by providing open learning programmes, individual learning options or other innovative programmes (Morris, 2019. Pp. 56-66).

\section{Mediators of self-organisation in education}

The important question is how to help students to develop independent learning skills. The answer to this question depends on the learning environment, in which students are immersed, as well as on the influence of the 'mediator', who may be a teacher, tutor or instructor (Crooks et al., 2001; Hiemstra, 2013). In different countries such 'mediators' are called differently, but they perform the same functions.

The mediator in the educational process based on self-organisation of students performs the following functions (Cruz Flores et al., 2011):

- helps students to structure their learning material using techniques that can identify their individual needs for topics covered in the course or in the training module and facilitate their independent in-depth study;

- after determining the needs of students, assists them in independent and deeper studies of specific topics, including this in the learning goals and objectives, which can be formalised as an individual curriculum written and agreed upon by the tutor and students;

- encourages students to use self-assessments (assessments of the results of their own activities) and choose methods that are appropriate for the content and type of learning in accordance with the desired goals; the tutor as a mediator can also use traditional methods of assessing the effectiveness of self-organisation (questionnaires, tests, interviews, etc.) or other forms of assessment; if it is necessary to increase the objectivity of the assessment, an additional expert can be involved;

- uses a variety of learning resources, helping students and expanding their capabilities in selecting materials for advanced learning to achieve their personal goals, including databases and online electronic resources, which today are an inexhaustible source of information necessary for the effective implementation of tasks facing students; 
- creates an optimal learning environment for personalising the educational process, which involves the use of various materials on the basis of seminars, discussions, working groups, additional classes provided online and additional learning materials,

- organises feedback with students and creates opportunities to adequately assess the students' experience individually or in a group; and

- structures the course of individual learning, starting with methods and approaches to learning and ending with the choice of class time that best suits the individual needs of students; taking into account these needs, the attendance of classes, grades and ways of receiving them are stipulated.

In addition, the use of new approaches to learning based on digital technologies, innovative learning methods and Internet resources can currently help students to strengthen their natural predisposition to self-organisation, promoting the lifelong learning process in the context of independence and freedom, and rational assessments without fear of errors in relation to the results of their learning and liberation from conventions that were always limiting, for example, in a formal approach to learning. At the same time, it should be noted that, like any approach to learning, the independent approach has its advantages and disadvantages, which must be taken into account in the process of its usage.

In the modern world, self-learning is attracting the increasing attention as one of the most promising educational methods (Joan, 2015). Currently, a significant number of different learning methods have appeared due to the use of the latest electronic technologies, and, consequently, the learning format itself must be changed. This increase in the choice of learning resources means that students have the opportunity to choose their own learning method (Manca, Ranieri, 2016).

\section{Criticism of the use of self-organisation in learning}

Basically, criticism of the use of self-organisation in learning is associated with its insufficient versatility. Self-organisation in learning, presumably, can undermine the idea of traditional education and cast doubt on the very system of generally accepted traditional approach to the educational system in society. However, this approach has its advantages, especially in the field of adult education. Our studies have shown that self-education is very effective when an informal learning model is used (Belovol et al., 2018).

Self-organisation in learning, with its characteristic democratic approach promoting independence and communication between teachers or students and teachers as equals, refers to the 'Western' learning styles that may be unacceptable for some other cultures. For example, in Asia or Africa, the traditional, authoritarian style often prevails, in which the goals are always clearly defined and control is associated with quantitative indicators in accordance with the requirements of national education systems. Students from these countries may turn out to be unprepared for self-learning. In this regard, they obviously need the help of a tutor and pedagogical support.

Studies on the self-organisation of Russian students show that it is negatively affected by the inability of students to resort to external resources when planning their activities in the absence of external control (Bobyliov, 2019). Students de- 
velop skills in the self-organisation of educational activities much more successfully if they are supported and controlled by teachers (Trofimov, 2017).

Thus, self-organisation in learning, in which there is no rigid and well-defined approach to the learning goals, can disorient students due to difficulties in finding clear parameters for assessing the results achieved in the learning process. In fact, self-organisation in learning may require answers to a number of important questions: what to evaluate, how to evaluate and in relation to what? In relation to the sensation of the usefulness of the life of the person or to his/her current and future work? In relation to the content of what is taught or the social consequences of learning? Or, perhaps, in relation to the achieved personality changes? And there may be quite a lot of such questions. Nevertheless, self-organisation in learning has several advantages.

\section{Advantages of the self-directed approach to learning}

Self-organisation in learning can contribute to the development of a new approach to education, which is based on real life conditions and learning experience (Gibbons, 2002; Grow, 1991). Self-organisation in education reflects the idea of the free choice in learning, taking into account the interests of students and helping them to realise their desires. This is particularly relevant in adult education. Self-organisation implies the idea of developing cooperative pedagogy, in which the freedoms of each person are perceived and interact in such a way that everyone can benefit from them (Guglielmino, 2008. Pp. 1-14).

Self-organisation in education and learning helps students to become proactive and committed to success, increase their self-assessments and feel satisfied with life and achieved results. Self-organisation in learning significantly increases the ability of students to make conscious choices in their favour, since in the process of self-learning they make decisions that take into account their own ideas, desires, aspirations, feelings and needs, and, therefore, they experience an increased sense of responsibility for the decisions made. Self-organisation in education encourages students, taking into account their real interests, to study topics in a wider and interdisciplinary context as compared with how it is done in the framework of educational disciplines. With the help of self-learning, the educational programme can be mastered with due account for the goals and the motivation emanating from the teacher, but in a more informal and democratic form (Barrios, Camargo Uribe, 2017).

Thus, the advantages of self-directed learning are as follows:

1) self-organisation in learning contributes to the practical implementation of the didactic principle of learning and development, which can be defined as a 'natural' sense of self-confidence, proactivity, commitment to success through learning, a sense of satisfaction with life and achieved results due to the accepted responsibility for the chosen lifestyle and the way to receive an education;

2) self-education based on self-organisation opens the door to a new interpretation of 'success in learning' and 'success in the educational process'. For example, an educational institution aimed at promoting self-education in learning should accept the fact that 'success' or 'failure' in the learning process are relative concepts and should be considered more globally, taking into account the development of 
the student's entire life and learning. This approach is especially important when success or failure in the educational process is actually determined by tests or quantitative assessment methods, which, no matter how objective they might be, are always stereotyped, containing imposed criteria and are aimed at assessing academic performance in learning the content that was not consciously selected by students themselves;

3) students' aspiration to self-organisation, if it is transformed into the real aspiration to development through continuing self-learning, allows them to have a much wider range of interests than it is possible in traditional learning with a clearly defined curriculum, a predetermined schedule and content, because the traditional school today is not able to satisfy all the needs and interests of students.

Self-organisation contributes to a deeper study of topics that, although included in academic disciplines, can yet be studied more widely, even at an interdisciplinary level, taking into account the specific interests of students themselves. Based on self-organisation, it becomes possible to transform the curriculum content in such a way as to motivate students to study it in accordance with the goals and objectives defined by the teacher.

Consequently, the knowledge that students will acquire, regardless of the restrictions associated with the formalised curriculum will be the result of the free choice rather than obtrusion. Without compulsory curricula, students are free to choose, plan, research and create, while learning what they want according to their goals, values that they intend to uphold and personal desires that they want to achieve through learning. This is precisely the main development trend of self-organisation in learning. Self-organisation in learning provides a new approach to education and learning in general: it reflects the idea of receiving an education without restrictions, the right to choose one's own way of receiving an education, to follow one's own interests with the aim of satisfying one's own desires and expectations (Sumuer, 2018). Self-organisation in education is based on the idea of the free choice.

Independence and self-direction in learning and work of students are achieved through the organisation of their work and acquisition of competencies, which they will implement when they are ready to devote time to them, in accordance with the planning, implementation and assessment of their own learning experience. Self-organisation is directly related to self-learning, since it is impossible to achieve success in educational activities without the correct time distribution and without the ability to set goals. Today, the process of self-education is impossible without the use of advanced technologies and learning resources.

\section{Experience in implementing self-organisation technologies in higher education}

The modern approach to self-organisation in higher education involves the use of various tools and methods. Various forms of independent work performed by students contribute to the formation and development of self-organisation in educational activities. In the process of scientific research work, students acquire the ability to formulate goals and organise their time. The use of various forms of independent work, including the remote learning format, is a prerequisite for self-organisation in educational activities. 
In formal learning, self-organisation means that students are involved in formulating the goals of their own learning activities, organising knowledge and constructing meaning using appropriate strategies that they consider necessary for the acquisition, development and generalisation of everything that has been studied (Lobato Fraile, 2006). The constructivist model of education allows students to learn by managing the process of their own learning. Constructivism suggests that students are products of their own abilities, which are used to acquire knowledge. In classrooms, pedagogical situations are created, solving which, students learn to actively construct knowledge. In this context, the University of Los Lagos (Santiago, Chile) developed in 2012 a student-oriented educational model based on competencies, which includes the search for new forms of relationships in teaching, much more flexible and creative approaches that, practically speaking, contribute to the solution of pedagogical problems, considering the student as the main protagonist in constructing learning. To ensure the achievement of these goals, the curriculum included disciplines that form 'transversal competencies for learning', which are a series of cognitive, emotional and social tools that can be used during the teaching process in harmony with the constructivist educational model (León Urquijo et al., 2014).

Recently, various social networks have been increasingly used for teaching and learning. For example, Facebook is used in different countries as a platform for online learning (Joan, 2015). This social network allows students from different countries and regions to organise self-directed learning, exchange ideas, participate in discussions of tasks, jointly develop research projects, watch videos, exchange information and always be in touch with the teacher and the group. Thus, Facebook can act as an ideal environment for the development of independent learning and the implementation of one's own educational strategies. Studies on the use of Facebook in learning emphasise the importance of social networks for implementing digital education and achieving learning goals in educational institutions (Duncan, Barczyk, 2016; Peruta, Shields, 2017). The data obtained confirm that Facebook, along with other social networks and the media, can expand the audience in the universities and make the educational process more creative and attractive.

Facebook provides collaboration and communication among communities focused on specific issues in certain areas of interest. When used in the structure of higher education, this network also helps to better implement the interaction between the teacher and students. In addition, Facebook can be useful in establishing new 'social contacts', which is very important for the processes of learning and socialisation in educational institutions. It should be noted that Facebook has the ability to integrate educational resources and applications on its platform to improve the quality of teaching and learning and allows teachers and students to optimise class time. Facebook also allows students to easily share seminar schedules, relevant materials, and Internet links. Modern educational platforms offering tools for communication, collaboration and learning are structured in such a way as to resemble Facebook. The basis of this one and other social networks is the availability of data: they are communication tools that can be used to facilitate the learning process and increase the involvement of students in independent learning activities (Ellefsen, 2016; Tugrul, 2017).

Students, as a rule, are good at using Facebook and do it to create groups and work on projects. In addition, the use of this network allows students to access 
networks, forums and chat rooms (for example, to obtain information on term papers) (Chugh, Umar, 2018). We can distinguish the following advantages of using Facebook as part of self-directed learning:

- easy access and exchange of resources, data, links, etc.;

- easy ways to create interest groups;

- integration of Facebook with mobile devices, which provides greater flexibility in the learning process; and

- support of the personalised educational process and its connection with real life.

The expansion of web-based communication and learning tools has opened up new learning opportunities, which include the use of social networks as learning tools in accordance with individual needs and interests (Caruso, 2018; Cuesta et al., 2016).

In addition to Facebook, there are some other electronic resources. The Moodle platform is used in the USA, Europe and Latin America. This platform hosts materials for various courses. This is a learning environment that allows users to create sites for online learning in different fields. This web application is very popular and used in remote learning. Moodle can be downloaded to any mobile device and used in learning. This web application allows users to take training courses, view their performance and activity in these courses and also communicate with other users.

The Coursera platform is a mass online education project with which universities from the USA, Latin America, China, India and European countries collaborate. Registered users can complete courses in specific disciplines or receive higher education in a distance format. Upon completion, in the case of successful learning, students receive certificates or diplomas. There are web forums created for participants in the courses, where joint learning and discussion of assignments is possible, but it is not allowed to copy and upload answers to assignments, while there are assignments that require anonymous mutual checks of students' answers. Some courses on this platform are recommended for end-of-term tests in universities. The learning process is organised in such a way that students can independently plan their time and choose a convenient schedule for listening to video materials and completing tasks, but within a specified period, i.e. tasks must be completed in a certain period; however, within this period, students independently organise their activities. Students who independently regulate the learning process should have a clear idea of their goals, study and control the learning environment.

In Russia, remote learning involves the Stepik platform, which in its structure is similar to Coursera. On this platform, registered users can choose free and fee-based training courses in various fields. Teachers are encouraged to create courses that can be used in remote learning. There are open courses where anyone can register on a free or paid basis and private courses where one can sign up after receiving an invitation from the teacher. To create a course, authors are provided with a free video studio in Saint Petersburg. For educational institutions, special profiles can be created. Taking a course does not have default date restrictions, but the course creator can adjust the opening dates of the modules so that they open gradually. Deadlines for students can also be customised. Upon successful com- 
pletion of learning, students receive certificates. Education at Stepik is free and convenient. Students themselves can come at any time, listen to lectures, read materials and complete assignments, receiving a certain number of points for correct answers. They can ask questions to the teacher. The courses provide forums for students to communicate with one other and with the teacher. The teacher has the opportunity to offer students assignments for mutual checks and mutual control. Although today this platform may be used not so actively as similar foreign platforms for higher education, it has good prospects in the field of remote education as well as an auxiliary tool in full-time education.

Thus, self-education, involving the use of advanced technologies and a remote format, requires that students intensify their independent activities and develop the ability to manage time and self-organisation skills.

\section{Conclusion}

Self-organisation is a kind of 'life philosophy', which refers to the 'philosophy of learning' and a personality trait that contributes to the effectiveness of learning. The success of the self-organisation process in higher education depends on a number of factors: volitional efforts and personal responsibility of students; the ability to work independently during learning; personality-centred learning; stable students' attitudes towards learning; the social significance of learning for students; and the ability to use advanced technologies based on digital learning methods and use of Internet resources. Of course, self-directed learning can never completely replace formal learning and become the ultimate goal of the educational process, but it can be an important part of education, affecting the formation of Homo educatus. Self-organisation opens up prospects for continuous lifelong learning.

\section{References}

Aristotle. Metaphysics. Retrieved from http://classics.mit.edu/Aristotle/metaphysics.html

Artelt, C., Baumert, J., McElvany, N., \& Peschar, J. (2003). Learners for Life. Student Approaches to Learning. Results from PISA 2000. Paris: OECD.

Barrios, A.H., \& Camargo Uribe, A. (2017). Autorregulación del aprendizaje en la educación superior en Iberoamérica: Una revisión sistemática. Revista Latinoamericana de Psicología, 49(2), 146-160. https://doi.org/10.1016/j.rlp.2017.01.001

Belovol, E.V., Bojko, Z.V., \& Shurupova, E.Yu. (2018). Education for whom for...: Modern approaches. Humanitarian bulletin SU "Pereyaslav-Khmelnitsky Pedagogical University by H. Skovoroda", 37(4), additional volume I(23): Thematic Issue "International Chelpanov's Psycho-Educational Reading" (pp. 146-157). (In Russ.)

Belovol, E.V., Boyko, Z.V., Radysh, I.V., \& Shurupova, E.Ju. (2018). Active aging: models of seniors' educational activity. Technologies of Living Systems, 4(15), 42-49. https://doi.org/10.18127/j20700997-201804-05 (In Russ.)

Belovol, E.V., Boyko, Z.V., Radysh, I.V., \& Shurupova, E.Ju. (2019). Life-long education: why do we need it? Technologies of Living Systems, 16(2), 63-68. https://doi.org/0.18127/j20700997-201902-07 (In Russ.)

Belovol, E.V., Boyko, Z.V., Radysh, I.V., \& Shurupova, E.Ju. (2016). Increase in person's selfrealization level as the result of third age education. Technologies of Living Systems, 7(13), 48-54. (In Russ.) 
Bobyliov, A.V. (2019). Difficulty in self-organization of educational activity. Yaroslavl Pedagogical Bulletin, 2(107), 30-35. https://doi.org/10.24411/1813-145X-2019-10348 (In Russ.).

Boyko, Z.V., Belovol, Ye.V., Groenwald, M., \& Siegień, W. (2014). Conception of lifelong education as a factor of life quality increasing for third age people (by the example of education in Poland). RUDN Journal of Psychology and Pedagogics, (4), 93-100. (In Russ.)

Brockett, R.G., \& Hiemstra, R. (1991). Self-Direction in Adult Learning: Perspectives on Theory, Research, and Practice. New York, NY: Routledge.

Brookfield, S. (2001). Understanding and Facilitating Adult Learning. San Francisco, CA: Jossey-Bass.

Candy, P.C. (1991). Self-direction for Lifelong Learning. San Francisco, CA: Jossey-Bass.

Caruso, Sh.J. (2018). Toward understanding the role of Web 2.0 technology in self-directed learning and job performance. Contemporary Issues in Education Research, 11(3), 89-98. https://doi.org/10.19030/cier.v11i3.10180

Cázares, Y. (2009). La autodirección, la persona autodirigida y sus componentes: definiciones conceptuales. El Tintero, $I X(38), 1-4$.

Cfr. Commissione Europea. Aprire l'istruzione: tecniche innovative di insegnamento e di apprendimento per tutti grazie alle nuove tecnologie e alle risorse didattiche aperte, [COM(2013) 654 final], documento disponibile online all'indirizzo: https://eurlex.europa.eu/legal-content/IT/ALL/?uri=LEGISSUM:4301337

Chugh, R., \& Umar, R. (2018). Social media in higher education: A literature review of Facebook. Education and Information Technologies, 23(2), 605-616.

Crooks, D., Lunyk-Child, O., \& Patterson, C. (2001). Facilitating self-directed learning. In E. Rideout (Ed.), Transforming Nursing Education through Problem-Based Learning (pp. 51-74). Boston, MA: Jones and Bartlett Publishers.

Cruz Flores, G., Chehaybar y Kury, E., \& Abreu, L.F. (2011). Tutoría en educación superior: Una revisión analítica de la literatura. Revista de la Educación Superior, XL(1), 189-209.

Cuesta, M., Eklund, M., Rydin, I., \& Witt, A. (2016). Using Facebook as a co-learning community in higher education. Learning, Media and Technology, 41(1), 55-72. https://doi.org/10.1080/17439884.2015.1064952

Descartes, R. Discourse on the Method of Rightly Conducting one's Reason and Seeking Truth in the Sciences. Retrieved from https://www.earlymoderntexts.com/assets/pdfs/descartes 1637.pdf

Duncan, D., \& Barczyk, C. (2016). Facebook's effect on learning in higher education: An empirical investigation. Information Systems Education Journal, 14(3), 14-28.

Ellefsen, L. (2016). An investigation into perceptions of Facebook-use in higher education. International Journal of Higher Education, 5(1), 160-172. https://doi.org/10.5430/ijhe.v5n1p160

Gibbons, M. (2002). The Self-Directed Learning Handbook: Challenging Adolescent Students to Excel. San Francisco, CA: Jossey-Bass.

Gibbons, M., \& Phillips, G. (1982). Self-education: The process of life-long learning. Canadian Journal of Education, VII(4), 67-86.

Grow, G. (1991). Teaching learners to be self-directed: A stage approach. Adult Education Quarterly, XLI(3), 125-149.

Guglielmino, L. (2008). Why self-directed learning? International Journal of Self-Directed Learning, $V(1), 1-14$.

Hiemstra, R. (2013). Facilitating adult self-directed learning. In R. Hiemstra, P. Carré (Eds.), A Feast of Learning: International Perspectives on Adult Learning and Change (pp. 25-45). Charlotte, NC: IAP Information Age Publishing.

Joan, R. (2015). Awareness of Facebook education among student teachers in present scenario. Journal on School Educational Technology, 10(4), 35-43.

Kant, I. Universal natural history and theory of heaven or essay on the constitution and the mechanical origin of the whole universe according to Newtonian principles. Retrieved from http://users.clas.ufl.edu/burt/spaceshotsairheads/Kantuniversalnaturalhistory.pdf

Knowles, M.S. (1970). The Modern Practice of Adult Education. New York, NY: Association Press. Knowles, M.S. (1975). Self-Directed Learning. New York, NY: Association Press. 
Knyazkova, O.N. (2014). Motivation and Value Aspects of Student's Personality Culture of Self-Organization. Chelovek i Obrazovanie (Man and Education), (3), 139-143 (In Russ.)

Kop, R., \& Fournier, H. (2010). New dimensions to self-directed learning in an open networked learning environment. International Journal of Self Directed Learning, VII(2), 2-20.

León Urquijo, A.P., Risco del Valle, E., \& Alarcón, S. (2014). Estrategias de aprendizaje en educación superior en un modelo curricular por competencias. Revista de la Educación Superior, XLIII(4), 123-144.

Lobato Fraile, C. (2006). Estudio y trabajo autónomos del estudiante. En Mario de Miguel Díaz (coord.), Metodologías de Enseñanza y Aprendizaje para el Desarrollo de Competencias. Madrid: Alianza Editorial.

Manca, S., \& Ranieri, M. (2016). Facebook and the others. Potentials and obstacles of Social Media for teaching in higher education. Computers \& Education, 95(1), 216-230. https://doi.org/10.1016/j.compedu.2016.01.012

Mandrikova, E.Yu. (2010). Razrabotka oprosnika samoorganizatsii deyatelnosti (OSD). Psikhologicheskaya Diagnostika, (2), 87-111. (In Russ.)

Merrian, S., \& Caffarella, R. (1991). Learning in Adulthood. A Comprehensive Guide. San Francisco, CA: Jossey Bass.

Morris, T.H. (2019). Adaptivity through self-directed learning to meet the challenges of our everchanging world. Adult Learning, 30(2), 56-66. https://doi:10.1177/1045159518814486

Narváez, M., \& Prada, A. (2005). Aprendizaje autodirigido y desempeño académico. Tiempo de Educar, VI(11), 115-146.

OECD-OCSE. (1996). Transitions to learning economies and societies in Lifelong learning for all. Meeting of the Education Commitee at Ministerial Level. Paris.

Olivares, S.L., \& López, M.V. (2014). Medición de la autopercepción de la autodirección en estudiantes de medicina de pregrado. Investigación en Educación Médica, IV(14), 75-80. https://doi.org/10.1016/S2007-5057(15)30005-3

Owen, R.T. (1999). Self-directed learning readiness among graduate students: Implications for orientation programs. Journal of College Student Development, XL(6), 739-743.

Pavlova, A.M. (2017). Pedagogical features of supporting the university students in the formation of self-organization skills of their activity. Obshchestvo: Sotsiologiya, Psikhologiya, Pedagogika, (7), 103-106. https://doi.org/10.24158/spp.2017 (In Russ.)

Peruta, A., \& Shields, A. (2017). Social media in higher education: Understanding how colleges and universities use Facebook. Journal of Marketing for Higher Education, 27(1), 131-143. https://doi.org/10.1080/08841241.2016.1212451

Plato. Republic. Book VI. Retrieved from http://classics.mit.edu/Plato/republic.7.vi.html

Smolyar, A.I., \& Knyazkova, O.N. (2016). Develop Students' Capacity for Reflection in Aspect of Culture of Self-Organization of Personality. Azimuth of Scientific Research: Pedagogy and Psychology, 5(4), 228-232. (In Russ.)

Sumuer, E. (2018). Factors related to college students' self-directed learning with technology. Australasian Journal of Educational Technology. 34(4), 29-43. https://doi.org/10.14742/ajet.3142

Trofimov, K.V. (2017). Self-Organization of Pedagogical University Junior Students as a Factor of Their Vital Activity Transformation in Academic and Extracurricular Work. The Science of Person: Humanitarian Researches, 4(30), 119-125. https://doi.org/10.17238/issn19985320.2017.30.119 (In Russ.)

Tugrul, T. (2017). Perceived learning effectiveness of a course Facebook page: Teacher-Led versus Student-Led approach. World Journal on Educational Technology, 9(1), 35-39. https://doi.org/10.18844/wjet.v9i1.1029

\section{Article history:}

Received: 27 May 2020

Revised: 5 July 2020

Accepted: 15 July 2020 


\section{For citation:}

De Martino, M., Gushchina, Yu.Sh., Boyko, Z.V., Magnanini, A., Sandor, I., Guerrero Perez, B.A., \& Isidori, E. (2020). Self-Organisation in Lifelong Learning: Theory, Practice and Implementation Experience Involving Social Networks and a Remote Format. RUDN Journal of Psychology and Pedagogics, 17(3), 373-389. http://dx.doi.org/10.22363/23131683-2020-17-3-373-389

\section{Bio notes:}

Mario De Martino, Ph.D. in Political Science, is Assistant Professor at Department of Marketing, at Erasmus project coordinator at Department of International Cooperation in Education and Science, Peoples' Friendship University of Russia (RUDN University) (Moscow, Russia). ORCID iD: https://orcid.org/0000-0002-3903-6532; Scopus Author ID: 57192676503, ResearcherID: AAN-8933-2020, eLIBRARY SPIN-code: 1128-5972. E-mail: de-martino-m@rudn.ru

Yulia Sh. Gushchina, Ph.D. in Pharmaceutical Sciences, is Associate Professor at Department of General and Clinical Pharmacology, Peoples' Friendship University of Russia (RUDN University) (Moscow, Russia). ORCID iD: https://orcid.org/0000-0003-1377-4796, ResearcherID: AAC-1738-2019, Scopus Author ID: 57211289379, eLIBRARY SPIN-code: 3851-2916. E-mail: gushchina-yush@rudn.ru

Zlata V. Boyko, Ph.D. in Psychology, is Associate Professor at Department of Management of Nursing Activities, Peoples' Friendship University of Russia (Moscow, Russia). ORCID iD: https://orcid.org/0000-0001-5313-8714, Scopus Author ID: 57191543556, Researcher ID: R-7738-2018, eLIBRARY SPIN-code: 7841-5255, E-mail: boikozv@yandex.ru

Angela Magnanini, Ph.D. in Educational Science, is Assistant Professor at Department of Movement, Human and Health Sciences, Foro Italico University of Rome (Rome, Italy). ORCID iD: https://orcid.org/0000-0001-8158-9272. E-mail: angela.magnanini@uniroma4.it

Iosif Sandor, Ph.D. in Educational Science, is Full Professor at Faculty of Physical Education and Sport, University of Cluj Babes-Bolyai (Cluj-Napoca, Romania). ORCID iD: https://orcid.org/0000-0003-2677-4568, Scopus Author ID: 55036933400. E-mail: iosif_ sandor@yahoo.com

Berta Alicia Guerrero Perez, Ph.D. in Jurisprudence, is Lawyer Consultant on Corporate Law of Russian Federation, Law Firm De la Cruz \& Partners Law Firm (Panama, Panama). ORCID iD: https://orcid.org/0000-0002-2202-3540, eLIBRARY SPIN-code: 4543-3984. E-mail: bertagperez@hotmail.com

Emanuele Isidori, Ph.D. in Physical Activity and Health, Ph.D. in Educational Sciences, Full Professor in General and Social Pedagogy, is Full Professor at Department of Movement, Human and Health Sciences, Foro Italico University of Rome (Rome, Italy). ORCID iD: https://orcid.org/0000-0002-5214-6015, Scopus Author ID: 55629929700, ResearcherID: C-9979-2011. E-mail: emanuele.isidori@uniroma4.it 


\title{
Самоорганизация в непрерывном образовании: теория, практика и опыт реализации с использованием социальных сетей и дистанционного формата
}

\author{
М. Де Мартино ${ }^{1}$, Ю.Ш. Гущина ${ }^{1}$, 3.В. Бойко ${ }^{1}$, А. Маньянини ${ }^{2}$, \\ И. Сандор ${ }^{3}$, Б.А. Герреро Перес ${ }^{4}$, Э. Исидори ${ }^{2}$ \\ ${ }^{1}$ Российский университет дружбы народов \\ Российская Федерация, 117198, Москва, ул. Миклухо-Маклая, 6 \\ ${ }^{2}$ Римский университет «Форо Италико» \\ Итальянская Республика, 00135, Рим, Пьяцциа Л. Де Босис, 6 \\ ${ }^{3}$ Университет Бабеша - Бойяи \\ Румыния, Клуж-Напока, 400000, Страда Пандурилор, 7 \\ ${ }^{4}$ Юридическая фирма «Де ла Круз и партнеры» \\ Республика Панама, Панама, 0823, Зона 7, ул. Караскилья, 74E
}

\begin{abstract}
Аннотация. В настоящее время в условиях глобального перехода мировой системы образования в дистанционный формат существенно актуализируются способность и готовность личности к самоорганизации учебной и профессиональной деятельности. В статье рассматриваются методологические подходы к самообразованию в контексте его использования в процессе непрерывного обучения, или обучения в течение всей жизни. Обсуждаются существующие концепции самообучения и формы его организации с учетом возрастных особенностей, форм и видов обучения. Анализируются понятия «самоорганизация» и «самообразование». Раскрывается сущность научных категорий «самообучение» и «самоорганизация в образовании» применительно к системе высшего образования. Показана роль тьютора как посредника в самоорганизации студента, описаны его основные функции в этом процессе. На основе теоретического анализа существующих форм самоорганизации в образовании и опыта ее использования описаны различные направления и возможности их применения на практике. Рассматривается критика использования самоорганизации в обучении и ее преимущества. Обсуждаются перспективы использования самоорганизации в высшем образовании. Подчеркивается важность и актуальность формирования самоорганизации как черты личности обучающихся. Описаны модели обучения, основывающиеся на самоорганизации обучающихся. Анализируется опыт реализации подхода самоорганизации к образовательному процессу. Делается вывод об успешности самообучения в случае социальной значимости обучения для субъекта, возможности применения новых технологий в обучении, основанных на цифровых методах и использовании интернет-ресурсов. Результаты исследования свидетельствуют о необходимости развития способностей к самоорганизации учебной деятельности, а также навыков самоконтроля и самооценки студентов, что особенно актуально в связи с увеличением доли самостоятельной работы в учебных программах и массовым переходом на дистантные формы обучения в высшем образовании в период пандемии COVID-19.
\end{abstract}

Ключевые слова: непрерывное образование, самообразование, самообучение, самоорганизация в образовании, непрерывное обучение, дистанционное образование, социальные сети

\section{История статьи:}

Поступила в редакцию: 27 мая 2020 г.

Принята к печати: 15 июля 2020 г. 


\section{Для цитирования:}

De Martino M., Gushchina Yu.Sh., Boyko Z.V., Magnanini A., Sandor I., Guerrero Perez B.A., Isidori E. Self-organisation in lifelong learning: theory, practice and implementation experience involving social networks and a remote format // Вестник Российского университета дружбы народов. Серия: Психология и педагогика. 2020. Т. 17. № 3. С. 373-389. http://dx.doi.org/10.22363/2313-1683-2020-17-3-373-389

\section{Сведения об авторах:}

Де Мартино Марио, кандидат политических наук, ассистент кафедры маркетинга экономического факультета, координатор проектов «Эразмус» департамента по международному научно-образовательному сотрудничеству, Российский университет дружбы народов (Москва, Россия). ORCID iD: https://orcid.org/0000-0002-39036532; Scopus Author ID: 57192676503, ResearcherID: AAN-8933-2020, eLIBRARY SPIN-код: 1128-5972. E-mail: de-martino-m@rudn.ru

Гущина Юлия Шамилевна, кандидат медицинских наук, доцент кафедры общей и клинической фармакологии, Медицинский институт, Российский университет дружбы народов (Москва, Россия). ORCID iD: https://orcid.org/0000-0003-1377-4796, ResearcherID: AAC-1738-2019, Scopus Author ID: 57211289379, eLIBRARY SPIN-код: 38512916. E-mail: gushchina-yush@rudn.ru

Бойко Злата Викторовна, кандидат психологических наук, доцент, доцент кафедры управления сестринской деятельностью, Медицинский институт, Российский университет дружбы народов (Москва, Россия). ORCID iD: https://orcid.org/0000-00015313-8714, Scopus Author ID: 57191543556, ResearcherID: R-7738-2018, eLIBRARY SPIN-код: 7841-5255. E-mail: boikozv@yandex.ru

Маньянини Анжела, Ph.D., ассистент кафедры наук об активности и здоровье человека, Римский университет «Форо Италико» (Рим, Италия). ORCID iD: https://orcid.org/00000001-8158-9272, ResearcherID: AAN-8495-2020. E-mail: angela.magnanini@uniroma4.it

Сандор Иосиф, Ph.D., профессор, факультет физического воспитания и спорта, Университет Бабеша - Бойяи (Клуж-Напока, Румыния). ORCID iD: https://orcid.org/00000003-2677-4568, Scopus Author ID: 55036933400, ResearcherID: AAO-2638-2020. E-mail: iosif_sandor@yahoo.com

Герреро Перес Берта Алисия, Ph.D., юрист-консультант по вопросам корпоративного права России (Панама, Панама). ORCID iD: https://orcid.org/0000-0002-2202-3540, eLIBRARY SPIN-код: 4543-3984. E-mail: bertagperez@hotmail.com

Исидори Эмануэле, Ph.D., профессор кафедры наук об активности и здоровье человека, Римский университет «Форо Италико» (Рим, Италия). ORCID iD: https://orcid.org/00000002-5214-6015, Scopus Author ID: 55629929700, ResearcherID: C-9979-2011. E-mail: emanuele.isidori@uniroma4.it 